\title{
ANALYSIS OF THE EFFECT OF HUMAN-WILDLIFE CONFLICT ON THE CONSERVATION OF FLORA AND FAUNA IN AKAGERA NATIONAL PARK-RWANDA
}

\author{
Lecturer Mangwa Kalisa Steven \\ University of Tourism, Technology and Business (UTB) Rwanda \\ DOI: 10.46609/IJSSER.2021.v06i03.002 URL: https://doi.org/10.46609/IJSSER.2021.v06i03.002
}

\begin{abstract}
The study analyzed the effect of the human and wildlife conflicts on wildlife conservation. The study was guided by three objectives: to investigate the nature of human and wildlife conflicts in Akagera National Park; to analyze of implications of human wildlife conflicts on wildlife conservation and to establish measures that could be adopted to mitigate human-wildlife conflicts in Akagera National Park. Data was collected by use of questionnaire and summarized in tables following the objectives of the study and frequencies and percentages were calculated based on the data available. The findings indicated that there are various effects of the human and wildlife conflicts on wildlife conservation in Akagera National Park effective information dissemination, high cost charged to tourists and lack of skilled staff are the challenges affecting the Human of conflicts on conservation. Sharing conservation-related benefits and involvement of local people in decision-making for resource management can increase the positive attitudes of local people towards wildlife, protected areas, and conservation practices. Participatory management and benefit sharing are best mechanisms, along with the granting to local communities of limited ownership rights for some resources. Measures that could be adopted to reduce the human of wildlife conflicts on wildlife conservation are improving marketing strategies, training of staff and service providers and improving the variety and accessibility of dark tourism attractions. Wildlife education and training activities are superior in disseminating innovative techniques, building local capacity, and increasing public understanding for humanwildlife conflict prevention and resolution. The study concluded that some of the challenges faced while undertaking conservation measures were; communities lacked necessary skills and training in conservation practices by the locals on wildlife policies and conservation management. The study recommended that communities must participate in park management planning and consulted in policy formulation. Relevant sectors such as the agricultural, livestock, tourism and lands must work together to ensure the communities realize their crop yields, and livestock production while coexisting with wildlife.
\end{abstract}




\section{International Journal of Social Science and Economic Research}

ISSN: $2455-8834$

Volume:06, Issue:03 "March 2021"

Key Words: Human Wildlife Conflict, Wildlife, Conservation

\section{Introduction}

Human-wildlife conflict is a growing problem in today crowded world, and can have significant impacts on both human and wildlife populations. Human-wildlife conflict occurs when there is close interaction between wild animals and human beings, resulting to injuries, death, predation, transmission of diseases and even human threats. Human beings in turn tend to retaliate back and even killing or injuring the same animals due to lack of compensation and proper framework to mitigate the conflict. Wildlife conservation is very important because wildlife and wilderness play an important role in maintaining the ecological balance and contribute to human quality of life (Akagera Management Company ,2015).

\section{Background to the study}

Human-wildlife conflict has been in existence for as long as humans and wild animals have shared the same landscapes and resources. Human-wildlife conflict does not occur only in Africa but around the world because humans have always defended themselves and their property from wild animals. All continents and countries, whether developed or not, are affected by human wildlife conflict. For example, the U.S. federal agency charged with controlling agricultural damages caused by wildlife spent over $\$ 60$ million in control operations during 2001 and estimated losses at nearly one billion dollars. Increasing global population, coupled with greater resource demands, has resulted in significant limitations to conservation and development goals on the margins of protected areas, particularly in middle- and low-income countries (Akagera Management Company,2015)

Human deaths and injuries, although less common than crop damage, are the most severe manifestations of HWC and are universally regarded as intolerable. Wildlife-human conflicts (WHC) are a serious obstacle to wildlife conservation and the livelihoods of people worldwide and are becoming more prevalent as human population increases, development expands, and global climate changes and other human and environmental factors put people and wildlife in greater direct competition for a shrinking resource base. In addition, as some wildlife conservation activities succeed, wildlife expands into human-dominated areas (Akagera Management Company, 2015).

In Rwanda's wildlife is rich and diversified and constitutes a unique natural heritage that is of great importance both nationally and globally. Wildlife resources contribute directly and indirectly to the local and national economies through revenue generation and wealth creation. Wildlife also plays critical ecological functions that are important for the interconnected web of life supporting systems, in addition to its socio-cultural and aesthetic values. Rwanda's wildlife 


\section{International Journal of Social Science and Economic Research}

ISSN: $2455-8834$

Volume:06, Issue:03 "March 2021"

protected areas significantly contribute to the production of global public goods and services, such as protection of biodiversity, climate stabilization, carbon sequestration and global waters.(African Parks ,2016)

Founded in 1934 to protect animals and vegetation, Akagera national park is the largest protected wetland in Africa (Akagera Management Company (2015).It was named after the Akagera River which flows along its eastern boundary. The park used to cover over 2,500 sq. km but in 1997; it was reduced in size by close to $50 \%$. A lot of the land was reallocated to refugees returning to Rwanda after the civil strife of the genocide. Before 1997, many refugees returning to Rwanda had settled in the area and the conservation area was harmed by poaching and cultivation (African Parks ,2016)

The four species of animals introduced in Akagera National Park from other areas: Rhinoceros were introduced in 1957 from Tanzania and there were more than 50 black rhinos in the Akagera National Park in the 1970s, but the numbers declined because of wide-scale poaching for the illegal horn trade. The last black rhino spotted in Rwanda was in 2007. However, in May 2017, Rwanda reintroduced around 20 eastern black rhinoceros from South-Africa to Akagera National Park after a 10 years absence (Agence France Presse. 2017). Elephants were introduced in 1975 from Bugesera area in Eastern Province of Rwanda, Giraffes were introduced in 1985 from Kenya and Lions reintroduced in 2015 from South Africa(African Parks ,2016).

Conflict management strategies earlier comprised lethal control, translocation and regulation of population size and preservation of endangered species. Recent management approaches attempt to use scientific research for better management outcomes, such as behavior modification and reducing interaction. As human-wildlife conflicts inflict direct, indirect and opportunity costs, the mitigation of human-wildlife conflict is an important issue in the management of biodiversity and protected areas (Akagera Management Company, 2015). Thus, with the main objective of this study was to analyze of effects of the human wildlife conflicts on Wildlife conservation in Akagera National park in Eastern Province.

\section{Statement of the Problem}

Human-wildlife conflict occurs when the needs and behavior of wildlife impact negatively on the goals of humans or when the goals of humans negatively impact the needs of wildlife (Cline et al, 2007). Rutagarama and Martin (2006), reported that Akagera has suffered more than other protected areas of Rwanda in terms of insecurity, lack of human and financial resources and conflict of interest between conservation and local livelihoods. Growing human population pressures, limited land resources have resulted in increased competition between local livelihoods and wildlife for scarcer sources threatening wildlife(RDB, 2012), 
The main challenges to the continued protection of Akagera National Park wildlife are population pressures, high rates of poverty and a high reliance on natural resources for livelihoods in the communities surrounding the park, forest fires, hunting pressures. These conflicts may result when wildlife damage crops, injure or kill domestic animals, threaten or kill people. Such conflict may occur because lions, leopards, hyena, crocodiles has attacked someone's livestock or an elephant, buffalo, has raided a person's crops. The conflict also occurs when a person or community seeks to kill the lion or elephant, buffalo, or when a person retaliates against the authorities that are in charge of conserving wildlife and its habitat. Human Wildlife Conflict, usually occurs when wildlife requirements overlap with those of humans, creating costs to residents and wild animals. Conflicts between wildlife and people, particularly those who share the immediate boundaries with protected areas are very common.(RDB, 2012.)This research is focusing to identify the kinds of the human wildlife conflicts in National Parks, analyze of effects of the human wildlife conflicts on Wildlife conservation and establish measures that could be adapted to human wildlife conflicts management.

\section{Objectives of the study}

\subsection{General objective of the study}

The main objective of this study is to analyze the effects of the human wildlife conflicts on wildlife conservation in Akagera National park.

\subsection{Specific objectives of the study}

a) To identify the nature of the human wildlife conflicts in Akagera National Park;

b) To analyze the implications of human wildlife conflicts on wildlife conservation in Akagera National Park

c) To establish the measures for managing human wildlife conflicts in Akagera National Park

\section{Literature Review}

\subsection{The kind of human wildlife conflicts in National Parks}

According to (Weber, 2007)., Human-wildlife Conflicts in National Parks can be categorized into following major types:

\begin{tabular}{|l|l|}
\hline Category & Description \\
\hline $\begin{array}{l}\text { Animal Attacks } \\
\text { on human beings }\end{array}$ & $\begin{array}{l}\text { Instances of attacks on human beings causing death / injury by wild } \\
\text { animals, such as crocodiles, hippopotamus, elephants, leopards, lions, }\end{array}$ \\
\hline \hline
\end{tabular}


International Journal of Social Science and Economic Research

ISSN: 2455-8834

Volume:06, Issue:03 "March 2021"

\begin{tabular}{|c|c|}
\hline & $\begin{array}{l}\text { rhinos and buffaloes. It may also include instances where people engaged } \\
\text { in unlawful activities are killed by wildlife or by law enforcement } \\
\text { agencies. }\end{array}$ \\
\hline $\begin{array}{l}\text { Destruction of } \\
\text { crops or houses }\end{array}$ & $\begin{array}{l}\text { Damage done by wildlife to property, e.g., agricultural crops, plantations, } \\
\text { residential areas etc. }\end{array}$ \\
\hline $\begin{array}{l}\text { Destruction of } \\
\text { Development } \\
\text { infrastructures }\end{array}$ & $\begin{array}{l}\text { Development Projects in the vicinity of national park/sanctuaries are } \\
\text { often destroyed by elephants. Such projects include but not limited to } \\
\text { water tanks, pipes and valley dams. }\end{array}$ \\
\hline $\begin{array}{l}\text { Domestic } \\
\text { animals' deaths }\end{array}$ & $\begin{array}{l}\text { Death or injury to cattle and other domestic animals like, dog, sheep } \\
\text { goat, etc.by wild animals, eg Lions, elephants and hyenas living in } \\
\text { national parks }\end{array}$ \\
\hline Illeg & $\begin{array}{l}\text { Traditional practice of killing or trapping any wild animal. Animal killed } \\
\text { intentionally by human beings for food or for sports. Instances where } \\
\text { people are arrested when accused of undertaking illegal activities such as } \\
\text { hunting or poaching for trade in wildlife, etc., are arrested }\end{array}$ \\
\hline $\begin{array}{l}\text { Minor forest } \\
\text { produce }\end{array}$ & $\begin{array}{l}\text { Minor forest produce are usually collected by local communities. During } \\
\text { such entries people may be injured or killed by wildlife, and they may } \\
\text { injure or kill wildlife. }\end{array}$ \\
\hline activities & $\begin{array}{l}\text { Tourism project can have adverse impact on the forest and wildlife, and } \\
\text { wildlife can also pose a threat to tourists. E.g. restrictions on safaris, } \\
\text { limits on number of vehicles allowed, Night traffic ban in reserves etc. }\end{array}$ \\
\hline $\begin{array}{l}\text { Wildlife injuries } \\
\text { and deaths }\end{array}$ & $\begin{array}{l}\text { Wildlife injured by poachers, hunters or anyone else without legal } \\
\text { authority. Wildlife killed or injured by train or by vehicles on roads/ } \\
\text { highways, electrocution and poisoning }\end{array}$ \\
\hline
\end{tabular}


International Journal of Social Science and Economic Research

ISSN: 2455-8834

Volume:06, Issue:03 "March 2021"

\subsection{Implications for Human-wildlife conflict on wildlife conservation}

The killing of wild animals in retaliation for incidents of human-wildlife conflict is a common reaction, even though the identification of the real culprit is seldom possible. Several species of large carnivores such as lions or hyenas have been eliminated from a large part of their former home ranges in response to human-wildlife conflict. Today, illegal persecution of predators, including poisoning, shooting and trapping, is still one of the greatest threats to these species (Smilie, Shaun, 2002). When a crocodile kills or injures a human, the human response is to kill or remove not just the individual crocodile responsible, but the whole local population. Humanwildlife conflict also has several indirect consequences. The transmission of diseases from domestic animals to wildlife, competition over grazing land, habitat fragmentation or pollution; all pose threats to the survival of wildlife populations or even the species as a whole(NaughtonTreves1999)

Human-induced wildlife mortality not only affects the population viability of some of the most endangered species, but also has a broader environmental impact on ecosystem equilibrium and biodiversity preservation. Conflict between human and wildlife today undoubtedly ranks among the main threats to conservation in National Parks alongside habitat destruction and commercially motivated hunting of wildlife to satisfy the demand for bushmeat and represents a real challenge to local, national and regional governments, wildlife managers, conservation and development agencies, and local communities (Naughton- Treves, 1999).

Conservation of wildlife outside protected areas cannot be achieved merely by protecting animals and avoiding the issues of people's needs and rights and their conflict with wildlife. Human-wildlife conflict, rural poverty and hunger, the prohibitive costs of wildlife lawenforcement arising from land use practices; all severely limit wildlife conservation outside Africa's national parks. The wildlife is causing major damage to crops and livestock, especially staple food crops(Naughton- Treves, 1999).

Habitat loss poses the greatest threat to species. The world's forests, swamps, plains, lakes, and other habitats continue to disappear as they are harvested for human consumption and cleared to make way for agriculture, housing, roads, pipelines and the other hallmarks of industrial development. Without a strong plan to create terrestrial and marine protected areas important ecological habitats will continue to be lost (Woodroffe et al,2005).

Habitat fragmentation is a less obvious consequence of development, reducing both the quantity and quality of habitat. Fragmentation is a process whereby large tracts of the natural landscape are gradually developed and subdivided until only patches of original habitat remain. When a species' habitat is separated by distances that make movement from one patch to another impossible, the impacts on the genetic health of the population are significant and reduce a 


\section{International Journal of Social Science and Economic Research}

ISSN: 2455-8834

Volume:06, Issue:03 "March 2021"

species ability to reproduce and withstand stress. In addition, smaller habitat patches and the wildlife that depend on them are more vulnerable to the catastrophic effects of natural disturbances such as fire and ice storms. Fragmentation also results in higher populations of generalist predators, resulting in increased predation on those species that attempt to use the remaining habitat blocks(Woodroffe e al, 2005).

The impact of human activity on wildlife extends beyond the actual area of development. When evaluating the impact of human activity on wildlife, we should consider a "disturbance zone" the entire area where habitat value has been meaningfully reduced. The encroachment of human activity into a natural area creates more "edge effects." Edge effects are changes in environmental conditions and animal behavior and well-being that result from being in close proximity to the border between habitat areas. Unlike natural borders, human disturbances often create "harder" edges with greater detrimental impacts on wildlife. Even seemingly small manmade disturbances, such as power line easements, can have major consequences for wildlife. In addition, the encroachment of human activity reduces the amount of interior habitat area relative to edge or border area. (Woodroffe et al, 2005).

\subsection{The measures for managing human wildlife conflicts}

Human-wildlife conflict can be managed through a variety of approaches. Prevention strategies endeavor to avoid the conflict occurring in the first place and take action towards addressing its root causes. Protection strategies are implemented when the conflict is certain to happen or has already occurred. Mitigation strategies attempt to reduce the level of impact and lessen the problem. By definition management techniques are only cost-effective if the cost of implementing the technique is less than the value of the damage, taking into account the fact that a short period of active management may have a continued effect, by instating longer-term protection of crops or herds. The various management possibilities are presented according to the characteristics of conflict (whether they relate to humans, production, animals and the environment), rather than according to their ability to prevent or mitigate damage (Viljoen, 2010).

Awareness raising can be carried out in the community at different levels, for instance in schools or in adult education arenas such as farmer field schools. Educating children, coupled with awareness raising among adults through the traditional authority of chiefs and headmen, would certainly be highly cost effective means of managing conflict.(Wally, 2017).

Education and training activities could be directed towards disseminating innovative techniques, building local capacity for conflict prevention and resolution, and increasing public understanding of human-wildlife conflict. Educating rural villagers in practical skills would help them deal with dangerous wild animal species and acquire and develop new tools for defending 


\section{International Journal of Social Science and Economic Research}

ISSN: 2455-8834

Volume:06, Issue:03 "March 2021"

their crops and livestock. Over time, it would result in a change of behavior among local populations and would contribute to reduced risks, improvements in local livelihoods and a reduction in their vulnerability. In an optimistic scenario, education and training would promote commitment towards conservation, raise awareness of the essential role of wildlife in ecosystem functioning and its ethical and economic value, as well as its recreational and aesthetic importance (Wally, 2017).

Education and training activities could be also directed towards disseminating innovative techniques, building local capacity for conflict prevention and resolution, and increasing public understanding of human-wildlife conflict. It is necessary to make local people realize and accept the idea and importance of wildlife protection. Public interaction can help in making local people responsible and cooperate in enforcement of wildlife management laws and regulations. Their feedback should also be taken for effective functioning of wildlife management. People should understand the concept of conservation of natural resources. The wildlife managers and other responsible persons should hold public discussions, shows, and talks and should also take help of other media like newspapers, magazines, radio and television to make people aware about the basic concepts behind wildlife management. This can stop people from exploiting natural resources, which is the major threat to wildlife and their habitats.(Viljoen, 2010).

.The role of education in public awareness programs is very important. There should be environmental subjects based on wildlife conservation in school and college curricula. The well-educated and trained specialists on environmental and forest issues should participate in public training and interact with people and solve their queries to make them more responsible towards their wildlife management duties. Nature interpretation centres may include setting up of educational camps or exhibition in nearby regions of protected areas such as zoological gardens, parks and wildlife sanctuaries. It is usually taken up by the concerned forest departments. The interpretation centres should be handled by qualified and trained staff in order to explain and motivate the concepts of wildlife management to the tourists and people of the nearby-protected areas. Wildlife management is operated at four basic levels: local, state, national and international. Government agencies plan the policies of protecting, conserving and managing wildlife. All the management levels participate in passing wildlife management tools and many a time, conflicts arise(Wally, 2017).

The payment of compensation in the event of loss is usually confined to a specific category of loss, such as human death or livestock killed by predators or elephants. These schemes are often funded by a conservation organization, although government schemes also exist. All are designed to increase damage tolerance levels among the affected communities and prevent them taking direct action themselves, such as hunting down and killing the elephants, lions or other 


\section{International Journal of Social Science and Economic Research}

ISSN: $2455-8834$

Volume:06, Issue:03 "March 2021"

species involved The failure of most compensation schemes is attributed to bureaucratic inadequacies, corruption, cheating, fraudulent claims, time and costs involved, moral hazards and the practical barriers that less literate farmers must overcome to submit a compensation claim( Cline et al, 2007).

The insurance scheme is an innovative compensation approach where farmers pay a premium for cover against a defined risk, such as livestock depredation. The premium can be set at the true market rate or be subject to subsidy provided by conservation organizations. The method also requires an accurate assessment of the cause of crop damage, livestock depredation, human injury or death, but because it operates on a more local scale, reports can be more easily verified. Although the insurance scheme can impose certain practices which need to be undertaken by participating farmers to avoid human-wildlife conflict, overall the method seems promising (Cline er al, 2007). Alternative compensation systems rely on giving out licenses to exploit natural resources, through tourism, hunting or collecting fuelwood, timber, mushroom, fodder, etc. This type of compensation scheme, also known as the "settlement of rights" to use natural resources, appears to be a more practical solution than monetary payment. (Rutagarama, and Martin2006).).

Where alternative land and incentives are available, the voluntary relocation of local communities to areas offering better access to natural resources and improved socio-economic opportunities can offer an adequate solution to managing human wildlife conflict Given the inadequate resources of most subsistence farmers in National Park, effective protection of crops or livestock is often unaffordable, time consuming and risky.Vigilance is an important component of crop or livestock protection and human wildlife conflict management. The fear of humans normally dissuades animals from committing damage (Wally, 2017)

Guard animals provide an alternative to a herder monitoring a flock, which is labor-intensive, time-consuming and costly. To be successful, a guard animal must bond with the animals they are to guard. Dogs can be effective in protecting homesteads and livestock from attack by predators. The dogs are trained to alert people to the presence of predators, rather than chasing predators. Donkeys have also been used as guard animals in many parts of the world(Rutagarama, and Martin, (2006).

If they are properly designed, constructed and maintained, fences can be almost completely effective in preventing conflict between people and wild animals. Fences are used to protect crops and to protect people and livestock. Fenced wildlife sanctuaries enable people to benefit yet be separated, from wildlife, so that they can practice other land uses such as pastoralism and agriculture. Several types of fences are used throughout Africa for various purposes. Plant hedges of various spiny cacti have the advantage of being a low-cost solution, effective against 


\section{International Journal of Social Science and Economic Research}

ISSN: $2455-8834$

Volume:06, Issue:03 "March 2021"

both carnivores and ungulates. On the other hand, they are slow to establish, do not deter baboons and elephants, and are often made of exotic species which can spread uncontrollably (Rutagarama, and Martin2006).

Fences constructed using strong material such as galvanized steel wire protects crops successfully against many mammals. The major factor limiting the wider use of wildlife fences is their cost, which varies depending on many factors such as topography, type of fence and the species it is designed to contain. The high maintenance cost of fencing is another limiting factor, which explains why fences are effective when managed by commercial farmers for high-value crops such as sugar cane or citrus. This option is beyond the means of emerging farmers or subsistence growers. Moreover, for some species, such as baboons, standard wire fencing is ineffective. Electric fencing is a more sophisticated and efficient solution. It is more durable, due to the reduced physical pressure from animals; it deters a wider range of species; and it is more aesthetically appealing. However, the cost of installation and maintenance is higher than for simple fences (Cline et al, 2007).

\section{Methodology}

This study adopted a descriptive survey research design which accordingto DiCicco-Bloom. \& Crabtree(2006), is a systematic, empirical inquiry into which the researcher does not have a direct control of independent variables as their manifestation has already occurred or they cannot be manipulated.

The population for this study was a cross section of 113 persons that were of interest to the researcher. Theyincluded staff of Akagera Management Company (AMC), local authorities and local community around of Akagera National Park (ANP).A stratified random sampling technique, based on the location of the village, was utilized to draw a sample from communities that live adjacent to the ANP. This was important to ensure equal chances of selection of households of both residing close and far from the national park. Two sectors of Rwinkwavu and Ndengo in the Kayonza district which border with the park were selected. The sample size was 56 which is $50 \%$ of the total population. According to DiCicco-Bloom. \& Crabtree(2006), 50\% of the total population is a representative sample.

Table 1. Target population and sample size

\begin{tabular}{|l|c|c|}
\hline Category of population & Target Population & Sample size \\
\hline Local community around ANP & 90 & 50 \\
\hline Akagera Management Company staff & 5 & 2 \\
\hline
\end{tabular}


International Journal of Social Science and Economic Research

ISSN: 2455-8834

Volume:06, Issue:03 "March 2021"

\begin{tabular}{|l|c|c|}
\hline Local authorities of Ndengo sector & 4 & 2 \\
\hline Local authorities of Rwinkwavu sector & 4 & 2 \\
\hline Total & 113 & 56 \\
\hline
\end{tabular}

Source. The researcher's field data, 2019

\section{Findings}

\subsection{The nature of the human wildlife conflicts in National Parks}

This section discusses whether kind of the human wildlife conflicts still exists in Akagera National Park. The table below shows the answers of the respondents whether kind of the human wildlife conflicts still exists in Akagera National Park.

Table 2. Existence of human wildlife conflicts in Akagera National Park.

\begin{tabular}{|c|c|c|c|}
\hline Human wildlife conflicts & Frequency & Percentage & Cumulative Percent \\
\hline Yes & 10 & $17.85 \%$ & 17.85 \\
\hline No & 46 & $82.14 \%$ & 100 \\
\hline Total & 56 & 100 & \\
\hline
\end{tabular}

Source. The researcher's field data, 2019

The findings in the table above show that $17.85 \%$ of the respondents answered Yes, which means that they accepted that the human wildlife conflicts still exist in Akagera National Park. On the contrary, $82.14 \%$ of the respondents answered No, which means that they didn't affirm that human wildlife conflicts still exist in Akagera National Park. Those who admitted that human -wildlife conflict exist in Akagera National Park explained that cases of poaching and wild animals' attacks on domestic animals and people are still prevalent in and around the park.

\subsection{The implications of the human wildlife conflicts on Wildlife conservation in ANP}

This section shows the implications of the human wildlife conflicts on Wildlife conservation in Akagera National Park. The table below shows the answers of the respondents about the effects of the human wildlife conflicts on Wildlife conservation in Akagera National Park. 
International Journal of Social Science and Economic Research

ISSN: 2455-8834

Volume:06, Issue:03 "March 2021"

Table 3. The Implication of the human wildlife conflicts on Wildlife conservation in ANP

\begin{tabular}{|c|c|c|c|c|c|c|}
\hline \multirow{2}{*}{$\begin{array}{l}\text { Implication of the } \\
\text { human wildlife } \\
\text { conflicts }\end{array}$} & \multicolumn{5}{|c|}{ Frequency/ Percentages } & \multirow[t]{2}{*}{ Totals } \\
\hline & Strongly agree & Agree & Uncertain & Disagree & Strongly disagree & \\
\hline Damage to crops, & $\begin{array}{c}5 \\
8.92 \%\end{array}$ & $\begin{array}{c}8 \\
14.28 \%\end{array}$ & $\begin{array}{c}6 \\
10.71 \%\end{array}$ & $\begin{array}{l}14 \\
25\end{array}$ & $\begin{array}{c}23 \\
41.07 \%\end{array}$ & $\begin{array}{c}56 \\
100 \%\end{array}$ \\
\hline $\begin{array}{l}\text { Local community } \\
\text { killing and hunting } \\
\text { wildlife }\end{array}$ & $0 \%$ & $\begin{array}{c}6 \\
10.71 \%\end{array}$ & $\begin{array}{c}15 \\
26.78 \%\end{array}$ & $\begin{array}{c}20 \\
35.71 \%\end{array}$ & $\begin{array}{c}15 \\
26.78 \%\end{array}$ & $\begin{array}{c}56 \\
100 \%\end{array}$ \\
\hline $\begin{array}{l}\text { Property damage } \\
\text { by wild animals }\end{array}$ & $\begin{array}{c}2 \\
3.57 \%\end{array}$ & $\begin{array}{c}7 \\
12.5 \%\end{array}$ & $\begin{array}{c}30 \\
53.57 \%\end{array}$ & $\begin{array}{c}9 \\
16.07 \%\end{array}$ & $\begin{array}{c}8 \\
14.28 \%\end{array}$ & $\begin{array}{r}56 \\
100 \%\end{array}$ \\
\hline $\begin{array}{l}\text { Death or Injuries } \\
\text { to people }\end{array}$ & $\begin{array}{c}24 \\
42.85 \%\end{array}$ & $\begin{array}{c}6 \\
10.71 \%\end{array}$ & $\begin{array}{c}4 \\
7.14 \%\end{array}$ & $\begin{array}{c}2 \\
3.57 \%\end{array}$ & $\begin{array}{c}20 \\
35.71 \%\end{array}$ & $\begin{array}{c}56 \\
100 \%\end{array}$ \\
\hline $\begin{array}{l}\text { Transmission of } \\
\text { diseases }\end{array}$ & $\begin{array}{c}1 \\
1.78 \%\end{array}$ & $\begin{array}{c}5 \\
8.92 \%\end{array}$ & $\begin{array}{c}5 \\
8.92 \%\end{array}$ & $\begin{array}{c}30 \\
53.57 \%\end{array}$ & $\begin{array}{c}15 \\
26.78 \%\end{array}$ & $\begin{array}{r}56 \\
100 \%\end{array}$ \\
\hline $\begin{array}{l}\text { Death or injury of } \\
\text { the domestic } \\
\text { animal }\end{array}$ & $\begin{array}{c}5 \\
8.92 \%\end{array}$ & $\begin{array}{c}7 \\
12.5 \%\end{array}$ & $\begin{array}{c}1 \\
1.78 \%\end{array}$ & $\begin{array}{c}15 \\
26.78 \%\end{array}$ & $\begin{array}{r}28 \\
50 \%\end{array}$ & $\begin{array}{r}56 \\
100 \%\end{array}$ \\
\hline $\begin{array}{l}\text { Reduction of } \\
\text { vegetation cover }\end{array}$ & $\begin{array}{c}2 \\
3.57 \%\end{array}$ & $\begin{array}{c}5 \\
8.92 \%\end{array}$ & $\begin{array}{c}9 \\
16.07 \%\end{array}$ & $\begin{array}{c}18 \\
32.14 \%\end{array}$ & $\begin{array}{c}22 \\
39.28 \%\end{array}$ & $\begin{array}{r}56 \\
100 \%\end{array}$ \\
\hline
\end{tabular}

Source. The researcher's field data, 2019

The implications of Human-wild life conflict on wildlife conservation in Akagera National park are many as shown in the above table. The implications aredamage to farmers crops by wild 


\section{International Journal of Social Science and Economic Research}

ISSN: 2455-8834

Volume:06, Issue:03 "March 2021"

animals, local community killing and hunting wildlife, property damage by wild animals, death or Injuries to people by wild animals, transmission of diseases from wild animals to domestic animals, death or injury of the domestic animals by wild animals and reduction of vegetation cover in the park. The implication of this incident on wild life conservation is that members of the community whose crops and livestock is damaged by wild animals or whose relatives are killed or injured by wild animalsor whose domestic animals suffer from diseases that are transmitted by wild animals by killing wild animals.retaliateby killing wild life and destroying their habit through burning park vegetation.

\subsection{The measures for managing human wildlife conflicts in Akagera National Park}

This section shows the answers of the respondents about the measures for managing human wildlife conflicts in Akagera National Park. The table below shows the measures can you suggest, so that the local community living around the ANP and Akagera Management Company in order to manage the human wildlife conflicts in Akagera National Park.

Table 4. The measures for managing human wildlife conflicts in Akagera National Park

\begin{tabular}{|c|c|c|c|c|c|c|}
\hline \multirow{2}{*}{$\begin{array}{l}\text { The measures for } \\
\text { managing human wildlife } \\
\text { conflicts in ANP }\end{array}$} & \multicolumn{5}{|c|}{ Frequency/ Percentages } & \multirow[b]{2}{*}{ Totals } \\
\hline & Strongly agree & Agree & Uncertain & Disagree & $\begin{array}{l}\text { Strongly } \\
\text { disagree }\end{array}$ & \\
\hline Education/awareness & $\begin{array}{c}25 \\
44.64 \%\end{array}$ & $\begin{array}{c}12 \\
21.42 \%\end{array}$ & $\begin{array}{c}8 \\
14.28 \%\end{array}$ & $\begin{array}{c}6 \\
10.71 \%\end{array}$ & $\begin{array}{c}5 \\
8.92 \%\end{array}$ & $\begin{array}{c}56 \\
100 \%\end{array}$ \\
\hline Compensation & $\begin{array}{c}26 \\
46.42 \%\end{array}$ & $\begin{array}{c}13 \\
23.21 \%\end{array}$ & $\begin{array}{c}7 \\
12.5 \%\end{array}$ & $\begin{array}{c}5 \\
8.92 \%\end{array}$ & $\begin{array}{c}10 \\
17.85 \%\end{array}$ & $\begin{array}{c}56 \\
100 \%\end{array}$ \\
\hline Voluntary relocation & $\begin{array}{c}5 \\
8.92 \%\end{array}$ & $\begin{array}{c}6 \\
10.71 \%\end{array}$ & $\begin{array}{c}20 \\
35.71 \%\end{array}$ & $\begin{array}{c}23 \\
41.07 \%\end{array}$ & $\begin{array}{c}2 \\
3.57 \%\end{array}$ & $\begin{array}{c}56 \\
100 \%\end{array}$ \\
\hline $\begin{array}{l}\text { revenue sharing with } \\
\text { local communities }\end{array}$ & $\begin{array}{c}30 \\
53.57 \%\end{array}$ & $\begin{array}{c}10 \\
17.85 \%\end{array}$ & $\begin{array}{c}6 \\
10.71 \%\end{array}$ & $\begin{array}{c}4 \\
7.14 \%\end{array}$ & $\begin{array}{c}6 \\
10.71 \%\end{array}$ & $\begin{array}{c}56 \\
100 \%\end{array}$ \\
\hline $\begin{array}{l}\text { Corporate social } \\
\text { responsibility/community }\end{array}$ & $\begin{array}{c}40 \\
71.42 \%\end{array}$ & $\begin{array}{c}15 \\
26.78 \%\end{array}$ & $\begin{array}{c}1 \\
1.78 \%\end{array}$ & $\begin{array}{c}0 \\
0 \%\end{array}$ & $\begin{array}{c}0 \\
0 \%\end{array}$ & $\begin{array}{c}56 \\
100 \%\end{array}$ \\
\hline Lethal control programs & 0 & $\begin{array}{c}0 \\
0 \%\end{array}$ & $\begin{array}{c}20 \\
35.71 \%\end{array}$ & 25 & $\begin{array}{c}11 \\
19.64 \%\end{array}$ & $\begin{array}{c}56 \\
100 \%\end{array}$ \\
\hline
\end{tabular}


International Journal of Social Science and Economic Research

ISSN: 2455-8834

Volume:06, Issue:03 "March 2021"

\begin{tabular}{|c|c|c|c|c|c|c|}
\hline & $0 \%$ & & & $44.64 \%$ & & \\
\hline $\begin{array}{l}\text { vigilance by } \mathrm{AMC} \\
\text { rangers }\end{array}$ & $\begin{array}{c}40 \\
71.42 \%\end{array}$ & $\begin{array}{c}8 \\
14.28 \%\end{array}$ & $\begin{array}{c}8 \\
14.28 \%\end{array}$ & $\begin{array}{c}0 \\
0 \%\end{array}$ & $\begin{array}{c}0 \\
0 \%\end{array}$ & $\begin{array}{c}56 \\
100 \%\end{array}$ \\
\hline $\begin{array}{l}\text { Avoiding the illegal } \\
\text { human activities in or } \\
\text { near of the parks. }\end{array}$ & $\begin{array}{c}36 \\
64.28 \%\end{array}$ & $\begin{array}{c}7 \\
12.5 \%\end{array}$ & $\begin{array}{c}10 \\
17.85 \%\end{array}$ & $\begin{array}{c}2 \\
3.57 \%\end{array}$ & $\begin{array}{c}1 \\
1.78 \%\end{array}$ & $\begin{array}{c}56 \\
100 \%\end{array}$ \\
\hline Fencing & $\begin{array}{c}50 \\
89.28 \%\end{array}$ & $\begin{array}{c}4 \\
7.14 \%\end{array}$ & $\begin{array}{c}2 \\
3.57 \%\end{array}$ & $\begin{array}{c}0 \\
0 \%\end{array}$ & $\begin{array}{c}0 \\
0 \%\end{array}$ & $\begin{array}{c}56 \\
100 \%\end{array}$ \\
\hline
\end{tabular}

Source. The researcher's field data, 2019

The findings in table above show that Akagera Management Company has put in place effects of human-wildlife conflict. Most of the respondents $66.06 \%$ who were interviewed agree that Akagera Management Company and local community has developed compensation scheme and creation of human wildlife conflict education and awareness with $69.63 \%$ for the affected people. AMC has also intensified its fencing to bar wild animals from freely moving to human habitat was rated highly with $96.42 \% \%$ of the respondents agree or strongly agree on the strategy and vigilance by AMC rangers with $85.7 \%$, Voluntary relocation program to those affected, lethal control programs and corporate social responsibility offered park management to try and mitigate HWC was also rated highly. Most respondents, 52\%, 64\% and 63\% respectively agree that the stated strategies are in existence.

\section{Conclusion}

Addressing human-wildlife conflict requires remarkable balance between conservation priorities and the need of the people who live around the wildlife palaces (areas). Many of Rwandan depend on land for their subsistence. The presence of many species of wildlife and the human activities done near wildlife habits boundary leads to conflict between the local people and nearby wildlife community. Therefore, it is necessary to create a mechanism that helps to manage the conflict and benefit the farmers from the wildlife and other natural resources around.

\section{Recommendations}

The Akagera Management Company should:

- Protect the health and safety of park staff, visitors, and wildlife from harm, diseases, and other risks associated with wildlife. 


\section{International Journal of Social Science and Economic Research}

ISSN: 2455-8834

Volume:06, Issue:03 "March 2021"

- Raise awareness of the public regarding the implications of their actions with respect to human-wildlife conflict;

- Formerly collaborate with local communities and other stakeholders adjacent to Akagera national park and strengthen the relationship between people and protected area staff; protect and restore the ecology within national parks and strengthen local economies through ecotourism development

\section{References}

1. African Parks (2016) Akagera National Park Achievements. Akagera Management Company, Kigali, Rwanda.

2. Agence France Presse. "Black rhinos return to Rwanda 10 years after disappearance". The Guardian, 3 May 2017.

3. Akagera Management Company (2015) Parc National de l'Akagera-Carte Touristique. Rwanda Development Board, Kigali.

4. Cline, R.; Sexton, N. \& Stewart, S.C. (2007). A human-dimensions review of humanwildlife disturbance: a literature review of impacts, frameworks, and management solutions (PDF) (Report). U.S. Geological Survey.

5. DiCicco-Bloom, B. \& Crabtree, B.F. (2006). The qualitative research inTourism and conservation Education.Newyork, USA

6. Naughton- Treves, L., (1999). Whose animals? A history of property right to wildlife in Akagera: Land degradation and development.

7. RDB, 2012. Muhazi and Akagera destination tourist map. RDB: Kigali. on 10 April 2013

8. RDB (2016), Community initiatives, Available at: http://www.rdb.rw/tourism-andconservation/conservation/community-initiatives.html (Accessed on 2/7/2019)

9. Rutagarama, E \& Martin, A. 2006. Partnerships for Protected Area Conservation in Rwanda.

10. Smilie, Shaun ( 2002). "Killer Cats Hunted Human Ancestors". National Geographic News. National Geographic Society. Archived from the original on 16 March 2014.

11. Viljoen, P. (2010). Akagera National Park, Rwanda, Aerial Wildlife Survey, August 2010. Unpublished report, African Parks, Akagera National Park, Rwanda.

12. Wally, C. (2017). Black rhino to return to Akagera National Park, Rwanda after 10-year absence: take note. Environmental Management. 
International Journal of Social Science and Economic Research

ISSN: 2455-8834

Volume:06, Issue:03 "March 2021"

13. Weber, B. (2007). Compensation Payments for Crop . Raiding and Livestock Depredation: An Overview of Issues and Options in Rwanda.

14. Woodroffe, Rosie; Thirgood, Simon; Rabinowitz, Alan, eds. (2005). People and wildlife: Conflict or Co-existence? Cambridge: Cambridge University Press. 